\title{
Pulmonary arterial hypertension: the case for a bioelectronic treatment
}

\author{
Despoina Ntiloudi ${ }^{1,2}$, Khaled Qanud', Jacquelyn-Nicole Tomaio' ${ }^{1}$, George Giannakoulas², Yousef Al-Abed' and
} Stavros Zanos ${ }^{1 *}$ (D)

\begin{abstract}
Pulmonary arterial hypertension (PAH) is a rare disease of unknown etiology that progresses to right ventricular failure. It has a complex pathophysiology, which involves an imbalance between vasoconstrictive and vasodilative processes in the pulmonary circulation, pulmonary vasoconstriction, vascular and right ventricular remodeling, systemic inflammation, and autonomic imbalance, with a reduced parasympathetic and increased sympathetic tone. Current pharmacological treatments for PAH include several classes of drugs that target signaling pathways in vascular biology and cardiovascular physiology, but they can have severe unwanted effects and they do not typically stop the progression of the disease. Pulmonary artery denervation has been tested clinically as a method to suppress sympathetic overactivation, however it is a nonspecific and irreversible intervention. Bioelectronic medicine, in particular vagus nerve stimulation (VNS), has been used in cardiovascular disorders like arrhythmias, heart failure and arterial hypertension and could, in principle, be tested as a treatment in PAH. VNS can produce pulmonary vasodilation and renormalize right ventricular function, via activation of pulmonary and cardiac vagal fibers. It can suppress systemic inflammation, via activation of fibers that innervate the spleen. Finally, VNS can gradually restore the balance between parasympathetic and sympathetic tone by regulating autonomic reflexes. Preclinical studies support the feasibility of using VNS in PAH. However, there are challenges with such an approach, arising from the need to affect a relatively small number of relevant vagal fibers, and the potential for unwanted cardiac and noncardiac effects of VNS in this sensitive patient population.
\end{abstract}

Keywords: Pulmonary arterial hypertension, Pathophysiology, Therapy, Bioelectronic medicine, Vagus nerve stimulation, Inflammation, Hemodynamics

\section{Background}

Pulmonary arterial hypertension (PAH) is a rare but severe disease. The estimated prevalence rate is between 6.6-26.0 cases per million, and the estimated incidence rate is between 1.1-7.6 cases per million adult inhabitants per year (Badesch et al. 2010; Escribano-Subias et al. 2012; Humbert et al. 2006; Ling et al. 2012; Peacock et al. 2007). The mean age of the patients, in the past, was 36 years, while today the mean age at diagnosis is between 50 and 65 years (Badesch et al. 2010; Foley et al. 2011; Hoeper et al., 2013b; Rich et al. 1987). In developing countries, the baseline data of patients with PAH remain largely unchanged (Jing et al. 2007).

\footnotetext{
* Correspondence: szanos@northwell.edu

'Institute of Bioelectronic Medicine, Feinstein Institutes for Medical Research, Manhasset, NY 11030, USA

Full list of author information is available at the end of the article
}

Over the last decades, survival rates of PAH patients have increased significantly (Thenappan et al. 2007). The main contributors to this outcome are earlier diagnosis due to increased awareness of the disease, referral to expert centers, administration of specific PAH therapy and improved special support strategies (Benza et al. 2012). However, the prognosis remains dismal: according to the REVEAL registry, the median survival of PAH patients is about 7 years (Benza et al. 2012). The progressive, fatal nature of the disease, combined with the high cost of pharmacotherapy and hospitalizations, has led to extensive research efforts focused on the development of new treatment options (Anand et al. 2016; McLaughlin et al. 2009). The scope of this article is to review the pathophysiological pathways of $\mathrm{PAH}$, to highlight the existing treatment options and their limitations, and to discuss

(c) The Author(s). 2019 Open Access This article is distributed under the terms of the Creative Commons Attribution 4.0 International License (http://creativecommons.org/licenses/by/4.0/), which permits unrestricted use, distribution, and 
the potential therapeutic use of a bioelectronic therapy based on vagus nerve stimulation.

\section{Pathophysiology of PAH}

In general, pulmonary circulation is a low pressure, low resistance system. PAH is defined as mean pulmonary arterial pressure (PAP) $\geq 25 \mathrm{mmHg}$ (in the proposed new definition the cut off for mean PAP is even lower $(>20 \mathrm{mmHg}))$ with pulmonary arterial wedge pressure $\leq 15 \mathrm{mmHg}$ and pulmonary vascular resistance $\geq 3$ Wood units (Galie et al. 2016; Simonneau et al. 2019). Arterial abnormalities in PAH cause the increase of pulmonary vascular resistance, which leads to a restriction of blood flow (Farber and Loscalzo 2004). The right ventricle (RV) becomes initially hypertrophic as a consequence of the increased afterload, which ultimately leads to right heart failure. The main mechanisms that cause the arterial abnormalities include vasoconstriction, endothelial-cell and smooth-muscle cell proliferation, in situ thrombosis, inflammation and formation of plexiform lesions (Archer and Rich 2000).

Chronic autonomic imbalance is common in $\mathrm{PAH}$ (Vaillancourt et al. 2017), with increased sympathetic (Nootens et al. 1995; Velez-Roa et al. 2004) and decreased parasympathetic activity (da Silva Goncalves Bos et al. 2018; Hemnes and Brittain 2018). In addition to, or perhaps partly because of, autonomic imbalance, the balance between vasodilators and vasoconstrictors, is disturbed in PAH (Farber and Loscalzo 2004). The production of vasodilators such as prostacyclin and nitric oxide (NO) are decreased in contrast with the production of vasoconstrictors, including endothelin and thromboxane, which are increased (Christman et al. 1992; Giaid et al. 1993). Furthermore, increased plasma levels of serotonin (5-hydroxytryptamine) might also play a role as vasoconstrictor and promoter of pulmonary artery smooth muscle cell proliferation in PAH (Herve et al. 1995; McLaughlin et al. 2009). Overexpression of 5hydroxytryptamine transporter was associated with the latter outcome (Eddahibi et al. 2001; Marcos et al. 2004). Dysfunction of voltage-gated $\mathrm{K}+$ channels lead also to pulmonary artery smooth muscle cell proliferation as well as vasoconstriction (Yuan et al. 1998).

Inflammation likely plays an important role in pathogenesis and progression of PAH , as well as in the development of RV failure (Kherbeck et al. 2013; Price et al. 2012; Rabinovitch et al. 2014; Voelkel et al. 2016). In patients with $\mathrm{PAH}$, there is histologic evidence of accumulation of inflammatory cells and elevated levels of cytokines and chemokines (Huertas et al. 2014; Humbert et al. 2019), both around pulmonary vessels (Nicolls and Voelkel 2017) as well as in the failing RV (Sun et al. 2017). The elevated cytokine levels are associated with impaired RV function (Prins et al. 2018) and reduced 5-year survival (Soon et al.
2010). Another evidence of immune dysregulation is the lymphoid neogenesis in the lungs of idiopathic PAH patients (Perros et al. 2012). Lymphoid neogenesis is related to chronic inflammatory processes, such as autoimmunity and infection (Aloisi and Pujol-Borrell 2006).

Other pathophysiologic pathways that are involved in PAH development are the imbalance in antithrombotic/ prothrombotic factors and growth inhibitors/ mitogen factors (Farber and Loscalzo 2004). Decreased apoptosis can be evoked due to mutations in the transforming growth factor-beta receptor pathway, such as in the bone morphogenetic protein receptor 2 and in the activin receptor-like kinase 1 and endoglin, which are associated with familial PAH (Lane et al. 2000; Trembath et al. 2001). Furthermore, the renin-angiotensin-aldosterone (RAA) system is up-regulated and in specific angiotensin II type 1 receptors expression and signaling which is increased in pulmonary arteries of patients with idiopathic $\mathrm{PAH}$, is associated with pulmonary artery smooth muscle cell proliferation (de Man et al., 2012b).

\section{Current therapies of PAH Pharmacologic therapies}

Calcium-channel blockers Approximately $10 \%$ of PAH patients have a positive acute vasoreactivity test (Galie et al. 2016). This is defined as a fall in mean pulmonary artery pressure (mean PAP) of $\geq 10 \mathrm{mmHg}$ to $\leq 40 \mathrm{~mm} \mathrm{Hg}$, with an unchanged or increased cardiac output after the administration of inhaled NO or iloprost, or intravenous epoprostenol or adenosine. Those patients are treated with high dose, progressively titrated, calcium channel blockers (Galie et al. 2016; Rich et al. 1992). However, if the patient after treatment with high dose of calcium channel blockers is in World Health organization (WHO) functional class III/ IV or his hemodynamic profile does not show marked improvement, initiation of specific PAH therapy is recommended (Galie et al. 2016). A study of Sitbon et al. showed that almost half of the acutely-vasoreactive patients were not long-term responders (Sitbon et al. 2005). Side effects of calcium channel blockers include hypotension, syncope and acute RV failure (Galie et al. 2016).

For all other cases, specific PAH therapy is followed and has three main pathophysiologic targets: endothelin, $\mathrm{NO} /$ cyclic guanosine monophosphate (cGMP), and prostacyclin.

\section{Endothelin pathway}

Bosentan, ambrisentan and macitentan are endothelin receptor antagonists. They are beneficial in PAH patients, improving their exercise capacity, WHO functional class and their hemodynamics, while slowing disease progression (Channick et al. 2001; Galie et al. 2008a, 2008b; Pulido et al. 2013; Rubin et al. 2002) The main adverse 
effects of endothelin receptor antagonists are abnormal liver function, increased incidence of peripheral edema and anemia (McLaughlin et al. 2009).

\section{NO/cGMP pathway}

Two types of drugs belong to the NO/cGMP pathway: phosphodiesterase type 5 inhibitors (sildenafil and tadalafil), which inhibit the degradation of cGMP, and riociguat, a guanylic cyclase stimulator that enhances cGMP production (Schermuly et al. 2008). Phosphodiesterase type 5 inhibitors were shown to improve the exercise capacity, WHO functional class, hemodynamics, quality of life, disease progression (Galie et al. 2009; Galie et al. 2005; Ghofrani et al. 2013; Sastry et al. 2004; Singh et al. 2006) and reduced $\mathrm{N}$-terminal pro B-type natriuretic peptide (Ghofrani et al. 2013). The most common adverse events were flushing, diarrhea and dyspepsia for sildenafil and headache and myalgia and flushing for tadalafil (Galie et al. 2009; Galie et al. 2005; Sastry et al. 2004). Syncope is the most common serious adverse events of riociguat (Ghofrani et al. 2013).

\section{Prostacyclin pathway}

Epoprostenol, iloprost, beraprost, treprostinil and selexipag constitute the category of drugs targeting the prostacyclin pathway. Epoprostenol is administered continually intravenously, iloprost requires multiple inhalations, usually six to nine times per day, treprostinil is administered subcutaneously, intravenously, inhaled and orally, while beraprost and selexipag is an orally administered selective prostacyclin receptor agonist. They have been shown to improve PAH symptoms, hemodynamics and exercise capacity and delay clinical worsening, while epoprostenol is the only compound to demonstrate reduced mortality in PAH patients (Badesch et al. 2000; Barst et al. 1996; Galie et al. 2002; Olschewski et al. 2002; Rubin et al. 1990; Simonneau et al. 2002; Sitbon et al. 2015). Common adverse events of prostanoids are headache, flushing, nausea, diarrhea, skin rash, musculoskeletal pain, jaw pain, infusion site pain for subcutaneous administration of treprostinil, and line infections for intravenous administration of epoprostenol (McLaughlin et al. 2009).

Regarding inhaled vasoactive intestinal peptide (VIP) and tyrosine kinase inhibitors, even though they theoretically seem promising medical therapies for PAH (Ghofrani et al. 2005; Leuchte et al. 2008; Nayyar et al. 2014; Petkov et al. 2003), their role in PAH treatment is controversial due to the recent negative clinical studies(Frost et al. 2015; Hoeper et al. 2013a,). Administration of imatinib although resulted in improved hemodynamics and exercise capacity, it increased significant adverse events and showed high discontinuation rate (Frost et al. 2015). The results from a randomized multicenter clinical trial phase II with subcutaneously administered VIP analogue are anticipated (NCT03556020).

Given that the PAH-specific therapy targets three different signaling pathways, in the case of inadequate treatment response or clinical worsening it is recommended that therapy is increased with sequential combination (Galie et al. 2016). Upfront combination therapy in WHO functional class II or III treatment-naive patients has also improved clinical outcome and is increasingly used in the therapeutic strategy in PAH (Galie et al. 2015). The favorable clinical results of combination therapy are supported additionally by the results of recent meta-analyses (Fox et al. 2016; Lajoie et al. 2016). In this context, it is likely that new treatment modalities could be considered as part of combination therapeutic schemes, even in PAH-specific treatment-naive patients.

Referral for transplantation in PAH patients is now postponed due to the wide use of specific PAH therapy, but when the maximal combination therapy fails and the patients remain severely symptomatic, transplantation is the only therapeutic option (Galie et al. 2016) (de Perrot et al. 2012; Fadel et al. 2010; Taylor et al. 2006; Toyoda et al. 2008).

\section{Drug therapies targeting the autonomic nervous system Alpha/Beta adrenergic receptor blockers}

Several mechanisms of action of beta blockers might support their use in PH. At the cellular level, beta blockers decrease RV myocardial hypertrophy and fibrosis, capillary rarefaction, apoptosis and inflammation (Bogaard et al. 2010; de Man et al. 2012a, 2013; Ishikawa et al. 2009; Perros et al. 2015). With regards to RV function, beta blockers reduce RV hypertrophy, increase RV and LV ejection fraction, decrease myocardial oxygen consumption and RV afterload (Perros et al. 2017). However, due to the reduction of heart rate and cardiac output, as well as the negative impact on exercise capacity (Bandyopadhyay et al. 2015; Provencher et al. 2006; Thenappan et al. 2014; van Campen et al. 2016), current guidelines do not recommend their use in $\mathrm{PH}$ patients except for those with comorbidities such as arrhythmia, high blood pressure, coronary artery disease and left heart failure (Galie et al. 2016).

\section{ACE inhibitors/Angiotensin-1 receptor inhibitors/ Mineralocorticoid receptor antagonists}

Dysregulation of renin-angiotensin-aldosterone system contributes to the pathophysiology of PAH (de Man et al. 2012b; Morrell et al. 1995). At a cellular level, this activation promotes vasoconstriction, cell proliferation, migration, extracellular matrix remodeling and fibrosis (Maron and Leopold 2014). Small studies with angiotensinconverting-enzyme (ACE) inhibitors, such as captopril, had conflicting results. Some studies had positive results, lowering the mean PAP and increasing the RV ejection fraction (Alpert et al. 1992; Ikram et al. 1982), but in others 
captopril had no effect in pulmonary circuit (Leier et al. 1983; Rich et al. 1982). Studies with angiotensin-1 receptor inhibitors were also inconclusive. In animal models, losar$\tan$ was reported to delay disease progression, decrease RV afterload and pulmonary vascular remodeling and restore RV-arterial coupling (de Man et al. 2012b); however, in other studies failed to prevent or reduce the ventricular afterload (Cassis et al. 1992; Kreutz et al. 1996). Only one small clinical study showed that losartan is not inferior to nifedipine with regards to mean PAP and exercise capacity (Bozbas et al. 2010). Since aldosterone plasma levels are high in PAH patients (Maron et al. 2013a) mineralocorticoid receptor antagonists were also tested as a possible therapeutic target (Maron et al. 2012; Preston et al. 2013). Indeed, in the trials for ambrisentan (ARIES) it was noted that patients treated with ambrisentan plus spironolactone had a trend toward better functional capacity and plasma-B-type natriuretic peptide (Maron et al. 2013a). However, there are not large clinical trials to support the role of these drugs in PAH patients, data from ongoing clinical trials are going to define their efficacy and torelability in these patients (Clinical-Trials.gov Identifier: NCT01712620, NCT03177603).

In general, the several classes of drugs targeting the autonomic nervous system and the renin-angiotensinaldosterone system, albeit the positive preclinical findings, have not shown definite clinical benefit and not widely recommended in PAH (Table 1).

\section{Invasive therapies}

Pulmonary artery denervation (PAD) is a clinicallytested non-pharmacological treatment of PAH. Given that sympathetic nerve activity in PAH is increased (Velez-Roa et al. 2004), ablation at the main bifurcation area of the left pulmonary artery (PAD) has been attempted as a treatment option in PAH (Chen et al. 2013a). In the preclinical context, PAD induced sympathetic nerve injury, including axon loss, demyelination, prolonged conduction time and loss of potential amplitude, improved the hemodynamics, reducing the mPAP and pulmonary vascular resistance and caused pulmonary artery remodeling (Chen et al. 2013b; Rothman et al. 2015; Zhou et al. 2015). In a single-center clinical study of PAD, favorable outcomes were reported with respect to hemodynamics, functional capacity and cardiac function assessed by echocardiography (Chen et al. 2013a; Chen et al. 2015). In a recent multicenter, randomized study, PAD improved hemodynamic and clinical outcomes compared to sildenafil in patients with combined pre- and postcapillary pulmonary hypertension associated with left heart failure (H. Zhang et al. 2019).

Even though the results of these non-controlled trials should be interpreted with caution, the effectiveness of PAD in PAH suggests that targeting the autonomic nervous system (ANS) in PAH via an invasive method could be a viable therapeutic strategy. Sympathetic ganglion block is an experimental therapy that, like PAD, also targets the over-activation of the sympathetic nervous system. Superior cervical ganglion or stellate ganglion block using local injections of an anesthetic agent have been tested in rodent models of $\mathrm{PAH}$, with encouraging results (Na et al. 2014). Finally, catheter-based renal artery denervation, an intervention that targets the activation of the sympathetic nervous system and the RAA system,

Table 1 Pharmacological and invasive therapies targeting the autonomic nervous system in pulmonary arterial hypertension

\begin{tabular}{|c|c|c|c|}
\hline Therapy & Mechanism of action in PAH & Drawbacks & Recommendation \\
\hline Alpha/ Beta blockers & $\begin{array}{l}\text { Reduction in: } \\
\text { - Right ventricular myocardial } \\
\text { hypertrophy and fibrosis } \\
\text {-capillary rarefaction } \\
\text {-apoptosis } \\
\text {-inflammation }\end{array}$ & $\begin{array}{l}\text { Reduction in heart rate, cardiac output and } \\
\text { exercise capacity }\end{array}$ & $\begin{array}{l}\text { PH patients with } \\
\text { comorbidities (arrhythmia, high } \\
\text { blood pressure, coronary artery } \\
\text { disease, left heart failure) }\end{array}$ \\
\hline $\begin{array}{l}\text { Renin-angiotensin-aldosterone } \\
\text { system inhibitors }\end{array}$ & $\begin{array}{l}\text { Reduction in: } \\
\text {-vasoconstriction } \\
\text {-cell proliferation } \\
\text {-extracellular matrix remodeling } \\
\text {-fibrosis }\end{array}$ & No beneficial effect in some studies & More clinical data needed \\
\hline Sympathetic ganglion block & $\begin{array}{l}\text { Suppression of activation of } \\
\text { the sympathetic nervous } \\
\text { system (SNS) }\end{array}$ & $\begin{array}{l}\text {-Non-specific } \\
\text {-Invasive } \\
\text {-Not readily reversible } \\
\text {-No clinical data }\end{array}$ & More data needed \\
\hline Renal artery denervation & $\begin{array}{l}\text { Suppression of activation of the } \\
\text { SNS and renin-angiotensin- } \\
\text { aldosterone system }\end{array}$ & $\begin{array}{l}\text {-Non-specific } \\
\text {-Invasive } \\
\text {-Irreversible } \\
\text {-No clinical data in PH }\end{array}$ & More data needed \\
\hline Pulmonary artery denervation & $\begin{array}{l}\text { Suppression of activation of } \\
\text { the SNS }\end{array}$ & $\begin{array}{l}\text {-Non-specific } \\
\text {-Invasive } \\
\text {-Irreversible }\end{array}$ & Being tested clinically \\
\hline
\end{tabular}


has been tested in a canine (Qingyan et al. 2015) and a rodent (Liu et al. 2017) model of PAH, again with encouraging results.

Drawbacks of these invasive approaches is that they are non-specific, since the ablation or block takes place without targeting specific branches or fiber types of the neural structures and that they are completely or partially irreversible (Table 1). This raises the possibility that a targeted, reversible method for modulating autonomic tone may be another viable, perhaps preferable, therapeutic approach in $\mathrm{PAH}$.

\section{Bioelectronic medicine and its cardiovascular applications Principles of bioelectronic medicine therapies}

Placement of neurostimulation probes in contact with nerves of the ANS to deliver therapeutic neuromodulation in diseases or conditions in which the ANS is implicated is a relatively new family of interventions, for which the terms "electroceuticals", "bioelectronic medicine" (BEM) (Famm et al. 2013) or "autonomic regulation therapies" (Dicarlo et al. 2013; Premchand et al. 2014) have been used. The basis of BEM therapies is that up- or down-modulation of the tone in specific parts of the ANS can have predictable effects on the afferent (sensory) information that is conveyed to the brain and on the efferent (motor) commands modulating the function of innervated organs. These effects can be acute or chronic, and typically involve alterations in the function of several organs and systems, depending on which nerve targets and fibers are stimulated, which autonomic reflexes are recruited by stimulation and which physiological adaptations occur in response to neurostimulation. BEM leverages these principles to develop neurostimulation therapies that target specific mechanisms and neural circuits that are affected or implicated in different diseases.

Targeting nerves with electrical stimulation to treat diseases has two major advantages over pharmaceutical therapies. First is specificity with regards to the targeted organ system: placing the probe on a specific nerve and using fiber-selective electrical stimulation waveforms can deliver the therapy specifically to the affected organ while engaging only the relevant autonomic fibers (Birmingham et al. 2014). Drugs, on the other hand, are delivered systemically and affect receptors on all tissues and organs. Second is specificity with regards to time: the timing of delivery of neurostimulation can be tightly controlled, even triggered by specific events or physiological states and not by others, i.e. only when therapy is needed and not continuously (Zanos 2018). Pharmaceuticals have typically sustained presence in the organism, determined by pharmacokinetics with time course that in not under our control once the drug is delivered. The cardiovascular system is controlled by many autonomic nerves and fibers and, in addition, has a highly dynamic physiology. For these reasons, cardiovascular diseases like $\mathrm{PAH}$ are, in principle, good candidates for BEM therapies.

The vagus nerve is a major autonomic nerve with increased therapeutic potential, for 2 reasons: first, because its afferent and efferent arms are involved in the sensory and motor innervation of practically all organs and, second, because its surgical approach at the cervical region is well-established, relatively easy, can be performed as an outpatient procedure.

\section{Bioelectronic medicine therapies of cardiovascular disorders}

The heart and vessels are heavily innervated by the ANS, both its sympathetic and parasympathetic arms. The autonomic innervation is involved in the continuous physiological control of cardiovascular function (Armour 2004; Hanna et al. 2017) and is implicated in the acute and chronic adaptive and maladaptive pathophysiological responses to diseases affecting the cardiovascular system (Armour 2004). As a result, targeting the autonomic innervation of the cardiovascular system using neurostimulation has been one of the first applications of the BEM approach, aimed at disorders like hypertension, heart failure and cardiac arrhythmias (Horn et al. 2019). For example, electrical stimulation of the carotid sinus nerve via an implantable device reduces blood pressure in some patients with drug-resistant hypertension by modulating the tone of the baroreflex (de Leeuw et al. 2017; Scheffers et al. 2010). Device-based interventions that target the cardiac vagus or the cardiac sympathetic nerves have successfully suppressed or prevented atrial and ventricular arrhythmias, both in animal models and in clinical trials (Waldron et al. 2019; Zhu et al. 2019).

More specifically, the therapeutic effects of VNS in experimental models of heart failure is of relevance to its potential use in the context of PAH. Stimulation of the cervical vagus in animal models of heart failure reduced heart rate, improved the systolic and diastolic function of the left ventricle, reversed left ventricular hypertrophy, and reduced the frequency of arrhythmias and sudden cardiac death (Sabbah et al. 2011); favorable effects were also documented in a clinical trial (Premchand et al. 2014). Some of these effects were independent of the VNS-induced reduction in heart rate (Y. Zhang et al. 2009); instead, several neural mechanisms, at multiple levels of the cardiac autonomic nervous system, have been implicated in these actions of VNS, including activation of the baroreflex (Y. Zhang et al. 2009) and modulation of intrathoracic cardiocardiac and central reflexes (Hanna et al. 2018). In addition, VNS may favorably affect cellular and structural markers of remodeling in the failing left ventricle (Beaumont et al. 2015; Sabbah et al. 2011). There is evidence that VNS might exert such actions through 
increased production of nitric oxide in the myocardium, down-regulation of gap junction proteins, changes in neural excitability in the intrinsic cardiac nervous system, in the metabolism of cardiomyocytes and apoptosisrelated proteins (Sabbah et al. 2011).

\section{The rationale for a bioelectronic treatment of pulmonary hypertension}

A BEM therapy of PAH, more specifically a therapy based on vagus nerve stimulation (VNS), would in principle target several major pathogenetic and pathophysiologic mechanisms, namely, pulmonary vasoconstriction, right ventricular dysfunction and systemic inflammation, as well as chronic autonomic imbalance (Fig. 2).

\section{Targeting pulmonary vasoconstriction and right ventricular dysfunction}

Vasoconstriction is one of the pathophysiological mechanisms of PAH. It is well-established that the autonomic nervous system is regulating pulmonary vascular tone (Farber and Loscalzo 2004; Hemnes and Brittain 2018; Mouratoglou et al. 2016). The respiratory track receives sympathetic innervation from neurons whose cell bodies reside mainly in the stellate ganglion and thoracic sympathetic chain ganglia T2-T5 (Kummer et al. 1992). The density along with the vascular reactivity to neurotransmitters decrease towards the periphery (Kummer 2011). The sympathetic nervous system causes vasoconstriction in lung vasculature and the responsible post-ganglionic neurotransmitter, norepinephrine, is reported to decrease compliance and increase resistance in pulmonary vascular bed (Knight et al. 1981). Both decreased compliance and increased resistance play a role in the development of PAH (Saouti et al. 2010). Intrapulmonary vessels are also innervated by parasympathetic neurons, which originate mainly from nucleus ambiguus (Hadziefendic and Haxhiu 1999) and provide cholinergic innervation through bronchopulmonary vagal branches (Fig. 1). Similarly to the sympathetic, the density of the parasympathetic fibers in the lung decreases towards the periphery; in addition, parasympathetic innervation is sparser compared to sympathetic (Kummer 2011). Stimulation of the efferent vagal nerve releases acetylcholine, which through a nitric oxide-dependent mechanism, causes dilation to the pulmonary vascular bed (McMahon et al. 1992). Acetylcholine can also downregulate the release of norepinephrine, acting on adrenergic terminals (Knight et al. 1981).

VNS could exert its protective effects by altering the function of the right ventricle (RV). VNS has been shown to increase RV contraction and relaxation (Henning et al. 1996). In a preliminary study in a rodent model of RV pressure overload, a condition that mimics RV dysfunction and the progressive development of RV failure in the presence of pulmonary hypertension, VNS normalized several indices of RV systolic function (Yoshida et al. 2018a). Some of those indices, for example RV end-systolic elastance, are independent of RV afterload, suggesting that VNS may be directly benefiting RV compensation to increased pressure in the pulmonary artery.

Along with pulmonary vasodilation and a direct effect on RV function, another potential, hemodynamically beneficial effect of VNS is suppression of supraventricular arrhythmias, with are most common in PAH patients (Y. Zhang and Mazgalev 2011; Zhu et al. 2019). Such a protective effect of VNS has been documented in post-operative patients receiving low-level VNS (Stavrakis et al. 2017) and, recently, in a population of patients newly diagnosed with atrial fibrillation (Stavrakis et al. 2019).

\section{Targeting systemic inflammation}

One of the well-established effects of VNS is downmodulation of the immune response to an acute inflammatory challenge, like the injection of lipopolysaccharide, a response that initiates in the spleen and includes coordinated production of inflammatory cytokines (Pavlov et al. 2018). A series of studies established a neuro-immune reflex, the inflammatory reflex, with an afferent and an efferent arm (Fig. 1). Briefly, the afferent arm starts with the axons of afferent neurons innervating the viscera; these neurons respond to noxious stimuli, fragments of pathogens and cytokines released by immune cells. Vagal sensory neurons have cell bodies in the nodose ganglion and project to the nucleus of the solitary tract in the brainstem. The efferent arm starts in the dorsal motor nucleus of the vagus, in the brainstem, continues with the efferent vagal fibers and synapses in the celiac ganglion; from there, noradrenergic neurons project to the spleen, where release of norepinephrine activates the release of choline acetyl-transferase (ChAT) positive CD4+ T-cells. In turn, these ChAT cells release acetyl choline, which acts on macrophages and other immune cells through $\alpha 7$ nicotinic receptors, resulting in suppression of proinflammatory cytokine production.

Since production and release of cytokines are central in the development of the acute and chronic inflammatory response, the physiologic and pathophysiologic role of the vagus in inflammation has been studied extensively (Pavlov et al. 2018). Activating the vagus system via VNS results in suppression of the release of tumor necrosis factor, interleukin1beta and other cytokines, and amelioration of the clinical and pathological consequences of inflammation. This has been successfully tested in animal models of endotoxemia (Borovikova et al. 2000), hemorrhagic shock (Guarini et al. 2004), sepsis (Huston et al. 2006), arthritis (Levine et al. 2014) and other autoimmune diseases (Tracey 2007), heart failure (Y. Zhang et al. 2009) etc. Suppression of the inflammatory reflex using VNS is explored as a therapeutic modality in clinical trials in patients with rheumatoid 


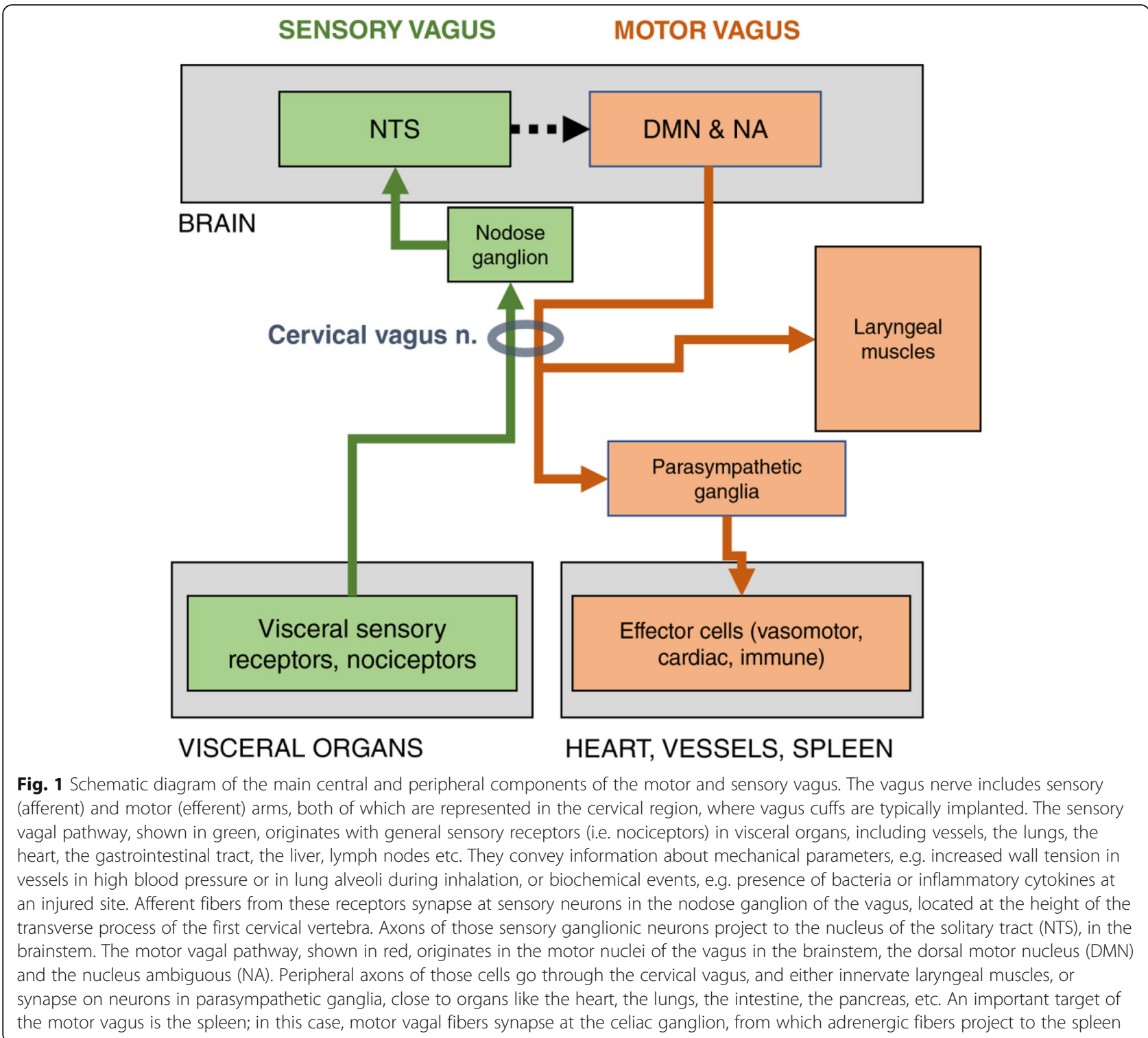

arthritis (Genovese et al. 2019; Koopman et al. 2016), lupus (Aranow et al. 2018) and inflammatory bowel disease (Bonaz et al. 2016).

In the context of PAH, suppression of systemic inflammation by VNS could ameliorate the pathological inflammatory process in the pulmonary vessels, slowing down or reversing vascular remodeling (Nicolls and Voelkel 2017), and in the right ventricle, protecting it from hypertrophy and maladaptive remodeling (Sun et al. 2017).

\section{Targeting autonomic imbalance}

In addition to the "direct" actions of VNS on pulmonary vasoconstriction and systemic inflammation, chronic VNS may gradually improve the imbalance between the sympathetic and parasympathetic tone which may contribute to, or be caused by, the inflammatory and hemodynamic aspects of PAH pathogenesis (Ameri et al. 2016) (Fig. 2). In a recent study in a rodent model of $\mathrm{PAH}$, it was shown that VNS for several weeks attenuated pulmonary vascular remodeling, preserved RV function and improved survival (Yoshida et al. 2018b); it accomplished that by chronically "re-setting" the balance between sympathetic and parasympathetic reflex circuits in the periphery and in the central nervous system (Kingma et al. 2018).

\section{Challenges for a bioelectronic treatment of pulmonary hypertension}

The direct, motor component of vasodilatory and antiinflammatory effects of VNS is primarily mediated by preganglionic, efferent, B-type, cholinergic vagal fibers. Therefore, a VNS-based treatment of PAH shouldprimarily target 


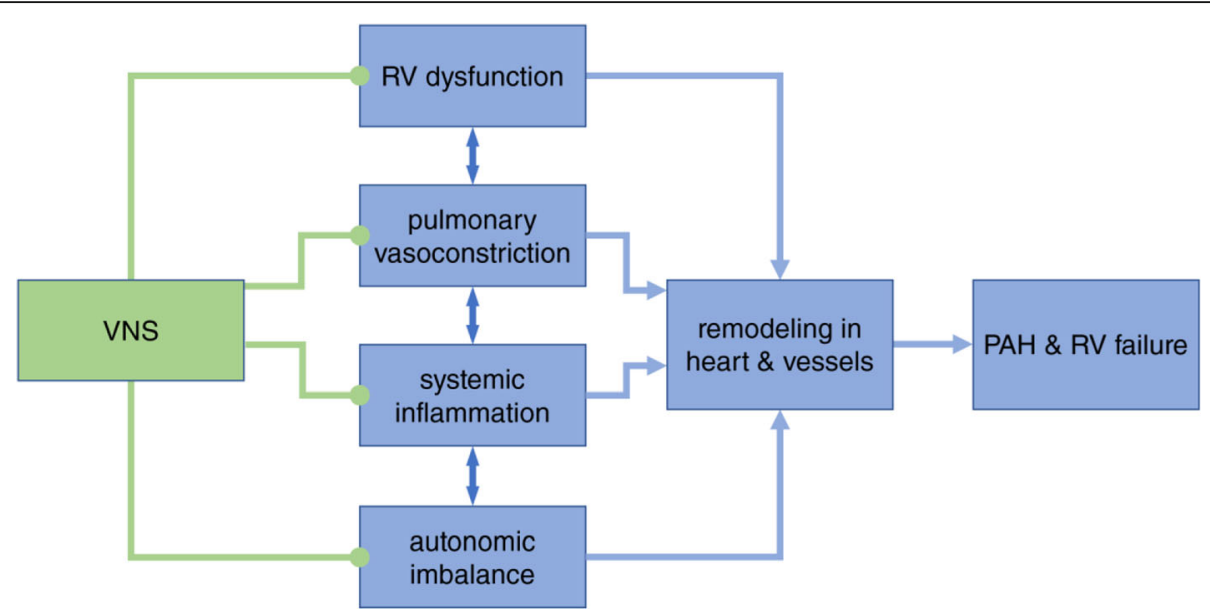

Fig. 2 Potential actions of VNS on different pathogenetic mechanisms involved in PAH. Pulmonary arterial vasoconstriction, right ventricular (RV) dysfunction and systemic inflammation are core mechanisms in the pathogenesis of PAH. They may be related to autonomic imbalance that is common in PAH, with an increased sympathetic and decreased parasympathetic tone. Vasoconstriction, RV dysfunction and inflammation lead to remodeling in the RV and pulmonary vessels, which eventually exacerbate the pathophysiology of PAH. In principle, VNS could target therapeutically these mechanisms in the following ways: VNS produces NO-mediated vasodilation in the pulmonary circulation via vagal bronchopulmonary branches. VNS renormalizes RV function via efferent and possibly afferent cardiac vagal fibers. VNS down-modulates cytokinemediated immune response via branches that terminate in the spleen. VNS chronically restores autonomic imbalance, possibly via re-setting vagal and non-vagal autonomic reflexes between the brain and periphery

cholinergic B-type fibers, ideally those innervating the pulmonary vessels and the spleen. Such an approach would have to overcome several challenges.

First, large, myelinated efferent A-type vagal fibers, some of which innervate muscles of the larynx and pharynx, have lower activation thresholds that the efferent, parasympathetic B-type fibers. Activation of those larger fibers gives rise to adverse effects like coughing, voice hoarseness, nausea etc., and frequently limits the intensity of cervical VNS to levels that are sub-therapeutic with regards to B-fibers. A potential solution could be to deliver stimulation to the cervical vagus that spares Atype and only targets B-type fibers using appropriate electrodes and stimulation waveforms, an area of active preclinical investigation (Guiraud et al. 2016; Musselman et al. 2019; Patel and Butera 2018).

Second, activation of large, myelinated afferent A-type fibers by VNS, again with lower activation thresholds than B-type fiber, may induce a reflexive decrease in parasympathetic tone and increase in sympathetic tone (Ardell et al. 2017). In addition, there is a small number of B-type, sympathetic, catecholaminergic fibers in the human vagus (Seki et al. 2014), and their activation by VNS could in principle directly enhance the sympathetic tone to the heart and vessels or stimulate sympathetic reflexes. Whatever the mechanism, a VNS-induced increase in sympathetic tone might exacerbate the pathophysiology of PAH. Therefore, it is important for a cervical VNS therapy to exert precise control over the relative amounts of the afferent and efferent parasympathetic and sympathetic activation, both direct and reflexive. Such cardiovascular control has been demonstrated experimentally in the cardiac vagus by fine-tuning specific VNS parameters, pulse width, intensity and pulsing frequency, according to the "neural fulcrum" hypothesis (Ardell et al. 2017).

Third, even if preganglionic, cholinergic fibers are successfully targeted, many of them innervate the heart. Cholinergic B-type fiber-specific VNS at the cervical level could have negative chronotropic, dromotropic and inotropic cardiac effects (Coote 2013), compromising the hemodynamic condition of patients with $\mathrm{PAH}$ who are sensitive to drops in cardiac output. A potential solution could be to use stimulation probes that specifically target fibers that innervate the lungs and/or the spleen. That could be attained, in principle, by implanting the probes closer to the end-organs, rather than at the cervical level. However, that would require more invasive surgery, as implanting a stimulation probe at the bronchial branch, or branches, of the vagus would require a thoracotomy, whereas implanting it at the splenic nerve would require a laparotomy. Thoracoscopy or laparoscopy could in principle be used instead. Alternatively, a cervical vagus electrode that specifically targets the pulmonary or splenic fibers could be used. That would require detailed knowledge of the branching pattern and radial distribution of pulmonary and splenic fibers at the level of the cervical vagus (Hammer et al. 2015), and fabrication of multi-contact, high-resolution stimulating electrodes that could target this kind of anatomical organization (Plachta et al. 2014).

Finally, activation of C-type afferent fibers by VNS might produce respiratory abnormalities (Coleridge and 
Coleridge 1984) including alterations in the breathing rhythm, bronchial mucus secretion, bronchoconstriction and cough (Undem and Kollarik 2005), and possibly changes in local bronchial and pulmonary neuroimmune and inflammatory reflexes, with unknown functional and clinical significance (Adriaensen and Timmermans 2011). However, activation of C-type fibers happens at much higher current intensities than those of B-type fibers (Heinbecker 1930) and can easily be avoided by calibration of VNS intensity (McAllen et al. 2018).

\section{Conclusions}

$\mathrm{PAH}$ is a lethal disease of the pulmonary circulation and the right heart. Its complex pathophysiology involves, among others, chronic autonomic imbalance, in particular reduction of the parasympathetic tone, pulmonary vasoconstriction, chronic inflammation, and vascular remodeling. A bioelectronic medicine therapy, by stimulating the vagus nerve, can target several of these processes, as VNS produces pulmonary vasodilation, suppresses inflammation and restores autonomic balance. Preliminary studies in preclinical animal models of PAH point to potentially therapeutic effects of VNS and warrant further investigations. Physiological studies of the hemodynamic and antiinflammatory effects of VNS in conditions and models that mimic PAH will help us understand the therapeutic potential of such an approach and drive patient selection criteria. Neurophysiological and biophysical studies in fiber-selective neurostimulation will result in modes of stimulation that recruit fibers in a desired manner, avoiding unwanted effects. Finally, anatomical and neural tracing studies of the organization of the vagal innervation of the lung vessels and the spleen in small and, primarily, in large animal models will guide the fabrication of more effective and selective stimulation probes for humans.

\section{Abbreviations \\ ANS: Autonomic nervous system; BEM: Bioelectronic medicine; ChAT: Choline acetyl-transferase; PAP: Pulmonary artery pressure; NO: Nitric oxide; PAD: Pulmonary artery denervation; PAH: Pulmonary arterial hypertension; RV: Right ventricle; VNS: Vagus nerve stimulation; WHO: World Health Organization \\ Acknowledgements \\ The authors would like to acknowledge Drs. Andrew Nelsen, Adam Silverstein and Gil Golden, of United Therapeutics Corp., and Drs. Lance Becker, Tom Coleman and Kevin Tracey, of the Feinstein Institute, for stimulating discussions and comments on the manuscript.}

\section{Authors' contributions}

DN and SZ wrote, edited and reviewed the final version of this manuscript. $K Q$, JNT, GG and YA edited and reviewed the final version of this manuscript. All authors read and approved the final manuscript.

\section{Funding}

Part of this research was supported by a grant from United Therapeutics to SZ.

Availability of data and materials

Not applicable
Ethics approval and consent to participate

Not applicable

\section{Consent for publication}

Not applicable

\section{Competing interests}

The authors declare that they have no competing interests.

\section{Author details}

${ }^{1}$ Institute of Bioelectronic Medicine, Feinstein Institutes for Medical Research, Manhasset, NY 11030, USA. ²Department of Cardiology, AHEPA University Hospital, Thessaloniki, Greece.

Received: 5 September 2019 Accepted: 8 November 2019

Published online: 10 December 2019

\section{References}

Adriaensen D, Timmermans JP. Breath-taking complexity of vagal C-fibre nociceptors: implications for inflammatory pulmonary disease, dyspnoea and cough. J Physiol. 2011;589(Pt 1):3-4. https://doi.org/10.1113/jphysiol.2010. 201434.

Aloisi F, Pujol-Borrell R. Lymphoid neogenesis in chronic inflammatory diseases. Nat Rev Immunol. 2006;6(3):205-17. https://doi.org/10.1038/nri1786.

Alpert MA, Pressly TA, Mukerji V, Lambert CR, Mukerji B. Short- and long-term hemodynamic effects of captopril in patients with pulmonary hypertension and selected connective tissue disease. Chest. 1992;102(5):1407-12. https:// doi.org/10.1378/chest.102.5.1407.

Ameri P, Bertero E, Meliota G, Cheli M, Canepa M, Brunelli C, Balbi M. Neurohormonal activation and pharmacological inhibition in pulmonary arterial hypertension and related right ventricular failure. Heart Fail Rev. 2016; 21(5):539-47. https://doi.org/10.1007/s10741-016-9566-3.

Anand V, Roy SS, Archer SL, Weir EK, Garg SK, Duval S, Thenappan T. Trends and Outcomes of Pulmonary Arterial Hypertension-Related Hospitalizations in the United States: Analysis of the Nationwide Inpatient Sample Database From 2001 Through 2012. JAMA Cardiol. 2016;1(9):1021-9. https://doi.org/10.1001/ jamacardio.2016.3591.

Aranow C, Lesser M, Mackay M, Anderson E, Zanos TP, Datta-Chaudhuri T, et al. Engaging the cholinergic anti-inflammatory pathway by stimulating the vagus nerve reduces pain and fatigue in patients with SLE (Abstract 2652). Chicago: Paper presented at the ACR/ARHP Annual Meeting; 2018.

Archer S, Rich S. Primary pulmonary hypertension: a vascular biology and translational research "Work in progress". Circulation. 2000;102(22):2781-91. https://doi.org/10.1161/01.cir.102.22.2781.

Ardell JL, Nier H, Hammer M, Southerland EM, Ardell CL, Beaumont E, et al. Defining the neural fulcrum for chronic vagus nerve stimulation: implications for integrated cardiac control. J Physiol. 2017;595(22):6887-903. https://doi. org/10.1113/JP274678.

Armour JA. Cardiac neuronal hierarchy in health and disease. Am J Physiol Regul Integr Comp Physiol. 2004;287(2):R262-71. https://doi.org/10.1152/ajpregu. 00183.2004.

Badesch DB, Raskob GE, Elliott CG, Krichman AM, Farber HW, Frost AE, et al. Pulmonary arterial hypertension: baseline characteristics from the REVEAL Registry. Chest. 2010;137(2):376-87. https://doi.org/10.1378/chest.09-1140.

Badesch DB, Tapson VF, McGoon MD, Brundage BH, Rubin LJ, Wigley FM, et al. Continuous intravenous epoprostenol for pulmonary hypertension due to the scleroderma spectrum of disease. A randomized, controlled trial. Ann Intern Med. 2000;132(6):425-34. https://doi.org/10.7326/0003-4819-132-6200003210-00002.

Bandyopadhyay D, Bajaj NS, Zein J, Minai OA, Dweik RA. Outcomes of betablocker use in pulmonary arterial hypertension: a propensity-matched analysis. Eur Respir J. 2015;46(3):750-60. https://doi.org/10.1183/09031936. 00215514.

Barst RJ, Rubin LJ, Long WA, McGoon MD, Rich S, Badesch DB, et al. A comparison of continuous intravenous epoprostenol (prostacyclin) with conventional therapy for primary pulmonary hypertension. N Engl J Med. 1996;334(5):296-301. https://doi.org/10.1056/nejm199602013340504.

Beaumont E, Southerland EM, Hardwick JC, Wright GL, Ryan S, Li Y, et al. Vagus nerve stimulation mitigates intrinsic cardiac neuronal and adverse myocyte remodeling postmyocardial infarction. Am J Physiol Heart Circ Physiol. 2015; 309(7):H1 198-206. https://doi.org/10.1152/ajpheart.00393.2015. 
Benza RL, Miller DP, Barst RJ, Badesch DB, Frost AE, McGoon MD. An evaluation of long-term survival from time of diagnosis in pulmonary arterial hypertension from the REVEAL Registry. Chest. 2012;142(2):448-56. https:// doi.org/10.1378/chest.11-1460.

Birmingham K, Gradinaru V, Anikeeva P, Grill WM, Pikov V, McLaughlin B, et al. Bioelectronic medicines: a research roadmap. Nat Rev Drug Discov. 2014; 13(6):399-400. https://doi.org/10.1038/nrd4351.

Bogaard HJ, Natarajan R, Mizuno S, Abbate A, Chang PJ, Chau VQ, et al. Adrenergic receptor blockade reverses right heart remodeling and dysfunction in pulmonary hypertensive rats. Am J Respir Crit Care Med. 2010; 182(5):652-60. https://doi.org/10.1164/rccm.201003-03350C.

Bonaz B, Sinniger V, Hoffmann D, Clarencon D, Mathieu N, Dantzer C, et al. Chronic vagus nerve stimulation in Crohn's disease: a 6-month follow-up pilot study. Neurogastroenterol Motil. 2016;28(6):948-53. https://doi.org/10. 1111/nmo.12792.

Borovikova LV, Ivanova S, Zhang M, Yang H, Botchkina Gl, Watkins LR, et al. Vagus nerve stimulation attenuates the systemic inflammatory response to endotoxin. Nature. 2000;405(6785):458-62. https://doi.org/10.1038/35013070.

Bozbas SS, Bozbas H, Atar A, Ulubay G, Oner Eyuboglu F. Comparative effects of losartan and nifedipine therapy on exercise capacity, Doppler echocardiographic parameters and endothelin levels in patients with secondary pulmonary hypertension. Anadolu Kardiyol Derg. 2010;10(1):43-9.

Cassis LA, Rippetoe PE, Soltis EE, Painter DJ, Fitz R, Gillespie MN. Angiotensin II and monocrotaline-induced pulmonary hypertension: effect of losartan (DuP 753), a nonpeptide angiotensin type 1 receptor antagonist. J Pharmacol Exp Ther. 1992;262(3):1168-72.

Channick RN, Simonneau G, Sitbon O, Robbins IM, Frost A, Tapson VF, et al. Effects of the dual endothelin-receptor antagonist bosentan in patients with pulmonary hypertension: a randomised placebo-controlled study. Lancet. 2001;358(9288):1119-23. https://doi.org/10.1016/s0140-6736(01)06250-x.

Chen SL, Zhang FF, Xu J, Xie DJ, Zhou L, Nguyen T, Stone GW. Pulmonary artery denervation to treat pulmonary arterial hypertension: the single-center, prospective, first-in-man PADN-1 study (first-in-man pulmonary artery denervation for treatment of pulmonary artery hypertension). J Am Coll Cardiol. 2013a;62(12):1092-100. https://doi.org/10.1016/j.jacc.2013.05.075.

Chen SL, Zhang H, Xie DJ, Zhang J, Zhou L, Rothman AM, Stone GW. Hemodynamic, functional, and clinical responses to pulmonary artery denervation in patients with pulmonary arterial hypertension of different causes: phase II results from the Pulmonary Artery Denervation-1 study. Circ Cardiovasc Interv. 2015;8(11):e002837. https://doi.org/10.1161/ circinterventions.115.002837.

Chen SL, Zhang YJ, Zhou L, Xie DJ, Zhang FF, Jia HB, et al. Percutaneous pulmonary artery denervation completely abolishes experimental pulmonary arterial hypertension in vivo. Eurolntervention. 2013b;9(2):269-76. https://doi. org/10.4244/eijv9i2a43.

Christman BW, McPherson CD, Newman JH, King GA, Bernard GR, Groves BM, Loyd JE. An imbalance between the excretion of thromboxane and prostacyclin metabolites in pulmonary hypertension. N Engl J Med. 1992; 327(2):70-5. https://doi.org/10.1056/nejm199207093270202.

Coleridge JC, Coleridge HM. Afferent vagal C fibre innervation of the lungs and airways and its functional significance. Rev Physiol Biochem Pharmacol. 1984; 99:1-110.

Coote JH. Myths and realities of the cardiac vagus. J Physiol. 2013;591(17):407385. https://doi.org/10.1113/jphysiol.2013.257758.

da Silva Goncalves Bos D, Van Der Bruggen CEE, Kurakula K, Sun XQ, Casali KR, Casali AG, et al. Contribution of Impaired Parasympathetic Activity to Right Ventricular Dysfunction and Pulmonary Vascular Remodeling in Pulmonary Arterial Hypertension. Circulation. 2018;137(9):910-24. https://doi.org/10.1161/ circulationaha.117.027451

de Leeuw PW, Bisognano JD, Bakris GL, Nadim MK, Haller H, Kroon AA, et al. Sustained Reduction of Blood Pressure With Baroreceptor Activation Therapy: Results of the 6-Year Open Follow-Up. Hypertension. 2017;69(5):836-43. https://doi.org/10.1161/HYPERTENSIONAHA.117.09086.

de Man FS, Handoko ML, van Ballegoij JJ, Schalij I, Bogaards SJ, Postmus PE, et al. Bisoprolol delays progression towards right heart failure in experimental pulmonary hypertension. Circ Heart Fail. 2012a;5(1):97-105. https://doi.org/10. 1161/circheartfailure.111.964494.

de Man FS, Tu L, Handoko ML, Rain S, Ruiter G, Francois C, et al. Dysregulated renin-angiotensin-aldosterone system contributes to pulmonary arterial hypertension. Am J Respir Crit Care Med. 2012b;186(8):780-9. https://doi.org/ 10.1164/rccm.201203-04110C. de Perrot M, Granton JT, McRae K, Pierre AF, Singer LG, Waddell TK, Keshavjee S. Outcome of patients with pulmonary arterial hypertension referred for lung transplantation: a 14-year single-center experience. J Thorac Cardiovasc Surg. 2012;143(4):910-8. https://doi.org/10.1016/j.jtcvs.2011.08.055.

Dicarlo L, Libbus I, Amurthur B, Kenknight BH, Anand IS. Autonomic regulation therapy for the improvement of left ventricular function and heart failure symptoms: the ANTHEM-HF study. J Card Fail. 2013;19(9):655-60. https://doi. org/10.1016/j.cardfail.2013.07.002.

Drake Jl, Gomez-Arroyo J, Dumur Cl, Kraskauskas D, Natarajan R, Bogaard HJ, et al. Chronic carvedilol treatment partially reverses the right ventricular failure transcriptional profile in experimental pulmonary hypertension. Physiol Genomics. 2013;45(12):449-61. https://doi.org/10.1152/physiolgenomics. 00166.2012.

Eddahibi S, Humbert M, Fadel E, Raffestin B, Darmon M, Capron F, et al. Serotonin transporter overexpression is responsible for pulmonary artery smooth muscle hyperplasia in primary pulmonary hypertension. J Clin Invest. 2001; 108(8):1141-50. https://doi.org/10.1172/jci12805.

Escribano-Subias P, Blanco I, Lopez-Meseguer M, Lopez-Guarch CJ, Roman A, Morales $P$, et al. Survival in pulmonary hypertension in Spain: insights from the Spanish registry. Eur Respir J. 2012;40(3):596-603. https://doi.org/10.1183/ 09031936.00101211.

Fadel E, Mercier O, Mussot S, Leroy-Ladurie F, Cerrina J, Chapelier A, et al. Long-term outcome of double-lung and heart-lung transplantation for pulmonary hypertension: a comparative retrospective study of 219 patients. Eur J Cardiothorac Surg. 2010;38(3):277-84. https://doi.org/10. 1016/j.ejcts.2010.02.039.

Famm K, Litt B, Tracey KJ, Boyden ES. A jump-start for electroceuticals. Nature. 2013:496:159-61.

Farber HW, Loscalzo J. Pulmonary arterial hypertension. N Engl J Med. 2004; 351(16):1655-65. https://doi.org/10.1056/NEJMra035488.

Foley RJ, Wilcox D, Walsh SJ, Azrin M, Hager WD. Survival of geriatric idiopathic pulmonary arterial hypertension patients. Conn Med. 2011;75(1):11-5.

Fox BD, Shtraichman O, Langleben D, Shimony A, Kramer MR. Combination Therapy for Pulmonary Arterial Hypertension: A Systematic Review and Metaanalysis. Can J Cardiol. 2016;32(12):1520-30. https://doi.org/10.1016/j.cjca. 2016.03.004.

Frost AE, Barst RJ, Hoeper MM, Chang HJ, Frantz RP, Fukumoto Y, et al. Longterm safety and efficacy of imatinib in pulmonary arterial hypertension. J Heart Lung Transplant. 2015;34(11):1366-75. https://doi.org/10.1016/j.healun. 2015.05.025.

Galie N, Barbera JA, Frost AE, Ghofrani HA, Hoeper MM, McLaughlin W, et al. Initial Use of Ambrisentan plus Tadalafil in Pulmonary Arterial Hypertension. N Engl J Med. 2015;373(9):834-44. https://doi.org/10.1056/NEJMoa1413687.

Galie N, Brundage BH, Ghofrani HA, Oudiz RJ, Simonneau G, Safdar Z, et al. Tadalafil therapy for pulmonary arterial hypertension. Circulation. 2009; 119(22):2894-903. https://doi.org/10.1161/circulationaha.108.839274.

Galie N, Ghofrani HA, Torbicki A, Barst RJ, Rubin LJ, Badesch D, et al. Sildenafil citrate therapy for pulmonary arterial hypertension. N Engl J Med. 2005; 353(20):2148-57. https://doi.org/10.1056/NEJMoa050010.

Galie N, Humbert M, Vachiery JL, Gibbs S, Lang I, Torbicki A, et al. 2015 ESC/ERS Guidelines for the diagnosis and treatment of pulmonary hypertension: The Joint Task Force for the Diagnosis and Treatment of Pulmonary Hypertension of the European Society of Cardiology (ESC) and the European Respiratory Society (ERS): Endorsed by: Association for European Paediatric and Congenital Cardiology (AEPC), International Society for Heart and Lung Transplantation (ISHLT). Eur Heart J. 2016;37(1):67-119. https://doi.org/10. 1093/eurheartj/ehv317.

Galie N, Humbert M, Vachiery JL, Vizza CD, Kneussl M, Manes A, et al. Effects of beraprost sodium, an oral prostacyclin analogue, in patients with pulmonary arterial hypertension: a randomized, double-blind, placebo-controlled trial. J Am Coll Cardiol. 2002;39(9):1496-502. https://doi.org/10.1016/s07351097(02)01786-2.

Galie N, Olschewski H, Oudiz RJ, Torres F, Frost A, Ghofrani HA, et al. Ambrisentan for the treatment of pulmonary arterial hypertension: results of the ambrisentan in pulmonary arterial hypertension, randomized, double-blind, placebo-controlled, multicenter, efficacy (ARIES) study 1 and 2. Circulation. 2008a;117(23):3010-9. https://doi.org/10.1161/circulationaha.107.742510.

Galie N, Rubin L, Hoeper M, Jansa P, Al-Hiti H, Meyer G, et al. Treatment of patients with mildly symptomatic pulmonary arterial hypertension with bosentan (EARLY study): a double-blind, randomised controlled trial. Lancet. 2008b;371(9630):2093-100. https://doi.org/10.1016/s0140-6736(08)60919-8. 
Genovese MC, Gaylis N, Sikes D. First-in-human study of novel implanted vagus nerve stimulation device to treat rheumatoid arthitis (Abstract LB0009). Madrid: Paper presented at the EULAR; 2019.

Ghofrani HA, Galie N, Grimminger F, Grunig E, Humbert M, Jing ZC, et al. Riociguat for the treatment of pulmonary arterial hypertension. N Engl J Med. 2013;369(4):330-40. https://doi.org/10.1056/NEJMoa1209655.

Ghofrani HA, Seeger W, Grimminger F. Imatinib for the treatment of pulmonary arterial hypertension. N Engl J Med. 2005;353(13):1412-3. https://doi.org/10. 1056/NEJMc051946.

Giaid A, Yanagisawa M, Langleben D, Michel RP, Levy R, Shennib H, et al. Expression of endothelin-1 in the lungs of patients with pulmonary hypertension. N Engl J Med. 1993;328(24):1732-9. https://doi.org/10.1056/ nejm199306173282402.

Guarini S, Cainazzo MM, Giuliani D, Mioni C, Altavilla D, Marini H, et al. Adrenocorticotropin reverses hemorrhagic shock in anesthetized rats through the rapid activation of a vagal anti-inflammatory pathway. Cardiovasc Res. 2004; 63(2):357-65. https://doi.org/10.1016/j.cardiores.2004.03.029.

Guiraud D, Andreu D, Bonnet S, Carrault G, Couderc P, Hagege A, et al. Vagus nerve stimulation: state of the art of stimulation and recording strategies to address autonomic function neuromodulation. J Neural Eng. 2016;13(4): 041002. https://doi.org/10.1088/1741-2560/13/4/041002.

Hadziefendic S, Haxhiu MA. CNS innervation of vagal preganglionic neurons controlling peripheral airways: a transneuronal labeling study using pseudorabies virus. J Auton Nerv Syst. 1999;76(2-3):135-45.

Hammer N, Glatzner J, Feja C, Kuhne C, Meixensberger J, Planitzer U, et al. Human vagus nerve branching in the cervical region. PLoS One. 2015;10(2): e0118006. https://doi.org/10.1371/journal.pone.0118006.

Hanna P, Rajendran PS, Ajijola OA, Vaseghi M, Andrew Armour J, Ardell JL, Shivkumar K. Cardiac neuroanatomy - Imaging nerves to define functional control. Auton Neurosci. 2017;207:48-58. https://doi.org/10.1016/j.autneu. 2017.07.008,

Hanna P, Shivkumar K, Ardell JL. Calming the Nervous Heart: Autonomic Therapies in Heart Failure. Card Fail Rev. 2018;4(2):92-8. https://doi.org/10. 15420/cfr.2018.20.2.

Heinbecker $\mathrm{P}$. The potential analysis of the turtle and cat sympathetic and vagus nerve trunks. Am J Physiol. 1930;93(1):284-306. https://doi.org/10.1152/ ajplegacy.1930.93.1.284.

Hemnes AR, Brittain EL. Autonomic Nervous System in Pulmonary Arterial Hypertension: Time to Rest and Digest. Circulation. 2018;137(9):925-7. https:// doi.org/10.1161/circulationaha.117.032355.

Henning RJ, Feliciano L, Coers CM. Vagal nerve stimulation increases right ventricular contraction and relaxation and heart rate. Cardiovasc Res. 1996; 32(5):846-53

Herve P, Launay JM, Scrobohaci ML, Brenot F, Simonneau G, Petitpretz P, et al. Increased plasma serotonin in primary pulmonary hypertension. Am J Med. 1995;99(3):249-54. https://doi.org/10.1016/s0002-9343(99)80156-9.

Hoeper MM, Barst RJ, Bourge RC, Feldman J, Frost AE, Galie N, et al. Imatinib mesylate as add-on therapy for pulmonary arterial hypertension: results of the randomized IMPRES study. Circulation. 2013a;127(10):1128-38. https://doi. org/10.1161/circulationaha.112.000765.

Hoeper MM, Huscher D, Ghofrani HA, Delcroix M, Distler O, Schweiger C, et al. Elderly patients diagnosed with idiopathic pulmonary arterial hypertension: results from the COMPERA registry. Int J Cardiol. 2013b;168(2):871-80. https:// doi.org/10.1016/j.jijcard.2012.10.026

Horn CC, Ardell JL, Fisher LE. Electroceutical Targeting of the Autonomic Nervous System. Physiology (Bethesda). 2019;34(2):150-62. https://doi.org/10.1152/ physiol.00030.2018.

Huertas A, Perros F, Tu L, Cohen-Kaminsky S, Montani D, Dorfmuller P, et al. Immune dysregulation and endothelial dysfunction in pulmonary arterial hypertension: a complex interplay. Circulation. 2014;129(12):1332-40. https:// doi.org/10.1161/circulationaha.113.004555.

Humbert M, Guignabert C, Bonnet S, Dorfmuller P, Klinger JR, Nicolls MR, et al. Pathology and pathobiology of pulmonary hypertension: state of the art and research perspectives. Eur Respir J. 2019;53(1). https://doi.org/10.1183/ 13993003.01887-2018.

Humbert M, Sitbon O, Chaouat A, Bertocchi M, Habib G, Gressin V, et al. Pulmonary arterial hypertension in France: results from a national registry. Am J Respir Crit Care Med. 2006;173(9):1023-30. https://doi.org/10.1164/rccm 200510-16680C.

Huston JM, Ochani M, Rosas-Ballina M, Liao H, Ochani K, Pavlov VA, et al. Splenectomy inactivates the cholinergic antiinflammatory pathway during lethal endotoxemia and polymicrobial sepsis. J Exp Med. 2006;203(7):1623-8. https://doi.org/10.1084/jem.20052362.

Ikram H, Maslowski AH, Nicholls MG, Espiner EA, Hull FT. Haemodynamic and hormonal effects of captopril in primary pulmonary hypertension. $\mathrm{Br}$ Heart J. 1982;48(6):541-5. https://doi.org/10.1136/hrt.48.6.541.

Ishikawa M, Sato N, Asai K, Takano T, Mizuno K. Effects of a pure alpha/betaadrenergic receptor blocker on monocrotaline-induced pulmonary arterial hypertension with right ventricular hypertrophy in rats. Circ J. 2009;73(12): 2337-41. https://doi.org/10.1253/circj.cj-09-0213.

Jing ZC, Xu XQ, Han ZY, Wu Y, Deng KW, Wang H, et al. Registry and survival study in chinese patients with idiopathic and familial pulmonary arterial hypertension. Chest. 2007;132(2):373-9. https://doi.org/10.1378/chest.06-2913.

Kherbeck N, Tamby MC, Bussone G, Dib H, Perros F, Humbert M, Mouthon L. The role of inflammation and autoimmunity in the pathophysiology of pulmonary arterial hypertension. Clin Rev Allergy Immunol. 2013;44(1):31-8. https://doi.org/10.1007/s12016-011-8265-z.

Kingma JG, Simard D, Rouleau JR. Autonomic nervous system and neurocardiac physiolopathology. In: Svorc P, editor. Autonomic nervous system. London: IntechOpen; 2018. p. 39-65.

Knight DS, Ellison JP, Hibbs RG, Hyman AL, Kadowitz PJ. A light and electron microscopic study of the innervation of pulmonary arteries in the cat. Anat Rec. 1981;201(3):513-21. https://doi.org/10.1002/ar.1092010308.

Koopman FA, Chavan SS, Miljko S, Grazio S, Sokolovic S, Schuurman PR, et al. Vagus nerve stimulation inhibits cytokine production and attenuates disease severity in rheumatoid arthritis. Proc Natl Acad Sci U S A. 2016;113(29):82849. https://doi.org/10.1073/pnas.1605635113.

Kreutz R, Fernandez-Alfonso MS, Ganten D, Paul M. Effect of losartan on right ventricular hypertrophy and cardiac angiotensin I-converting enzyme activity in pulmonary hypertensive rats. Clin Exp Hypertens. 1996;18(1):101-11.

Kummer W. Pulmonary vascular innervation and its role in responses to hypoxia: size matters! Proc Am Thorac Soc. 2011;8(6):471-6. https://doi.org/10.1513/ pats.201101-013MW

Kummer W, Fischer A, Kurkowski R, Heym C. The sensory and sympathetic innervation of guinea-pig lung and trachea as studied by retrograde neuronal tracing and double-labelling immunohistochemistry. Neuroscience. 1992;49(3):715-37. https://doi.org/10.1016/0306-4522(92)90239-X.

Lajoie AC, Lauziere G, Lega JC, Lacasse Y, Martin S, Simard S, et al. Combination therapy versus monotherapy for pulmonary arterial hypertension: a metaanalysis. Lancet Respir Med. 2016;4(4):291-305. https://doi.org/10.1016/s22132600(16)00027-8.

Lane KB, Machado RD, Pauciulo MW, Thomson JR, Phillips JA 3rd, Loyd JE, et al. Heterozygous germline mutations in BMPR2, encoding a TGF-beta receptor, cause familial primary pulmonary hypertension. Nat Genet. 2000;26(1):81-4. https://doi.org/10.1038/79226.

Leier CV, Bambach D, Nelson S, Hermiller JB, Huss P, Magorien RD, Unverferth DV. Captopril in primary pulmonary hypertension. Circulation. 1983;67(1):155-61. https://doi.org/10.1161/01.cir.67.1.155.

Leuchte HH, Baezner C, Baumgartner RA, Bevec D, Bacher G, Neurohr C, Behr J. Inhalation of vasoactive intestinal peptide in pulmonary hypertension. Eur Respir J. 2008;32(5):1289-94. https://doi.org/10.1183/09031936.00050008.

Levine YA, Koopman FA, Faltys M, Caravaca A, Bendele A, Zitnik R, et al. Neurostimulation of the cholinergic anti-inflammatory pathway ameliorates disease in rat collagen-induced arthritis. PLoS One. 2014;9(8):e104530. https:// doi.org/10.1371/journal.pone.0104530.

Ling Y, Johnson MK, Kiely DG, Condliffe R, Elliot CA, Gibbs JS, et al. Changing demographics, epidemiology, and survival of incident pulmonary arterial hypertension: results from the pulmonary hypertension registry of the United Kingdom and Ireland. Am J Respir Crit Care Med. 2012;186(8):790-6. https:// doi.org/10.1164/rccm.201203-03830C.

Liu Q, Song J, Lu D, Geng J, Jiang Z, Wang K, et al. Effects of renal denervation on monocrotaline induced pulmonary remodeling. Oncotarget. 2017;8(29): 46846-55. https://doi.org/10.18632/oncotarget.15154.

Marcos E, Fadel E, Sanchez O, Humbert M, Dartevelle P, Simonneau G, et al. Serotonin-induced smooth muscle hyperplasia in various forms of human pulmonary hypertension. Circ Res. 2004;94(9):1263-70. https://doi.org/10. 1161/01.res.0000126847.27660.69.

Maron BA, Leopold JA. The role of the renin-angiotensin-aldosterone system in the pathobiology of pulmonary arterial hypertension (2013 Grover Conference series). Pulm Circ. 2014;4(2):200-10. https://doi.org/10.1086/675984.

Maron BA, Opotowsky AR, Landzberg MJ, Loscalzo J, Waxman AB, Leopold JA. Plasma aldosterone levels are elevated in patients with pulmonary arterial 
hypertension in the absence of left ventricular heart failure: a pilot study. Eur J Heart Fail. 2013a;15(3):277-83. https://doi.org/10.1093/eurihf/hfs173.

Maron BA, Waxman AB, Opotowsky AR, Gillies H, Blair C, Aghamohammadzadeh $\mathrm{R}$, et al. Effectiveness of spironolactone plus ambrisentan for treatment of pulmonary arterial hypertension (from the [ARIES] study 1 and 2 trials). Am J Cardiol. 2013b;112(5):720-5. https://doi.org/10.1016/j.amjcard.2013.04.051.

Maron BA, Zhang YY, White K, Chan SY, Handy DE, Mahoney CE, et al. Aldosterone inactivates the endothelin-B receptor via a cysteinyl thiol redox switch to decrease pulmonary endothelial nitric oxide levels and modulate pulmonary arterial hypertension. Circulation. 2012;126(8):963-74. https://doi. org/10.1161/circulationaha.112.094722.

McAllen RM, Shafton AD, Bratton BO, Trevaks D, Furness JB. Calibration of thresholds for functional engagement of vagal $A, B$ and $C$ fiber groups in vivo. Bioelectron Med (Lond). 2018;1(1):21-7. https://doi.org/10.2217/bem2017-0001.

McLaughlin W, Archer SL, Badesch DB, Barst RJ, Farber HW, Lindner JR, et al. ACCF/AHA 2009 expert consensus document on pulmonary hypertension: a report of the American College of Cardiology Foundation Task Force on Expert Consensus Documents and the American Heart Association: developed in collaboration with the American College of Chest Physicians, American Thoracic Society, Inc., and the Pulmonary Hypertension Association. Circulation. 2009;119(16):2250-94. https://doi.org/10.1161/ circulationaha.109.192230.

McMahon TJ, Hood JS, Kadowitz PJ. Pulmonary vasodilator response to vagal stimulation is blocked by $\mathrm{N}$ omega-nitro-L-arginine methyl ester in the cat. Circ Res. 1992;70(2):364-9. https://doi.org/10.1161/01.res.70.2.364.

Morrell NW, Morris KG, Stenmark KR. Role of angiotensin-converting enzyme and angiotensin II in development of hypoxic pulmonary hypertension. Am J Physiol. 1995;269(4 Pt 2):H1186-94. https://doi.org/10.1152/ajpheart.1995.269. 4.H1186.

Mouratoglou SA, Giannakoulas G, Deftereos S, Giannopoulos G, Angelidis C, Cleman MW, Vassilikos VP. Intra--and Intercellular Calcium Handling in Pulmonary Arterial Hypertension. Med Chem. 2016;12(2):162-9.

Musselman ED, Pelot NA, Grill WM. Empirically Based Guidelines for Selecting Vagus Nerve Stimulation Parameters in Epilepsy and Heart Failure. Cold Spring Harb Perspect Med. 2019;9(7). https://doi.org/10.1101/cshperspect.a034264.

Na S, Kim OS, Ryoo S, Kweon TD, Choi YS, Shim HS, Oh YJ. Cervical ganglion block attenuates the progression of pulmonary hypertension via nitric oxide and arginase pathways. Hypertension. 2014;63(2):309-15. https://doi.org/10. 1161/HYPERTENSIONAHA.113.01979.

Nayyar D, Muthiah K, Kumarasinghe G, Hettiarachchi R, Celermajer D, Kotlyar E, Keogh A. Imatinib for the treatment of pulmonary arterial hypertension and pulmonary capillary hemangiomatosis. Pulm Circ. 2014;4(2):342-5. https://doi. org/10.1086/675996.

Nicolls MR, Voelkel NF. The Roles of Immunity in the Prevention and Evolution of Pulmonary Arterial Hypertension. Am J Respir Crit Care Med. 2017;195(10): 1292-9. https://doi.org/10.1164/rccm.201608-1630PP.

Nootens M, Kaufmann E, Rector T, Toher C, Judd D, Francis GS, Rich S. Neurohormonal activation in patients with right ventricular failure from pulmonary hypertension: relation to hemodynamic variables and endothelin levels. J Am Coll Cardiol. 1995;26(7):1581-5. https://doi.org/10.1016/07351097(95)00399-1.

Olschewski H, Simonneau G, Galie N, Higenbottam T, Naeije R, Rubin LJ, et al. Inhaled iloprost for severe pulmonary hypertension. N Engl J Med. 2002; 347(5):322-9. https://doi.org/10.1056/NEJMoa020204.

Patel YA, Butera RJ. Challenges associated with nerve conduction block using kilohertz electrical stimulation. J Neural Eng. 2018;15(3):031002. https://doi. org/10.1088/1741-2552/aaadc0.

Pavlov VA, Chavan SS, Tracey KJ. Molecular and Functional Neuroscience in Immunity. Annu Rev Immunol. 2018;36:783-812. https://doi.org/10.1146/ annurev-immunol-042617-053158.

Peacock AJ, Murphy NF, McMurray JJ, Caballero L, Stewart S. An epidemiological study of pulmonary arterial hypertension. Eur Respir J. 2007;30(1):104-9. https://doi.org/10.1183/09031936.00092306.

Perros F, de Man FS, Bogaard HJ, Antigny F, Simonneau G, Bonnet S, et al. Use of beta-Blockers in Pulmonary Hypertension. Circ Heart Fail. 2017;10(4). https:// doi.org/10.1161/circheartfailure.116.003703.

Perros F, Dorfmuller P, Montani D, Hammad H, Waelput W, Girerd B, et al. Pulmonary lymphoid neogenesis in idiopathic pulmonary arterial hypertension. Am J Respir Crit Care Med. 2012;185(3):311-21. https://doi.org/ 10.1164/rccm.201105-09270C.
Perros F, Ranchoux B, Izikki M, Bentebbal S, Happe C, Antigny F, et al. Nebivolol for improving endothelial dysfunction, pulmonary vascular remodeling, and right heart function in pulmonary hypertension. J Am Coll Cardiol. 2015;65(7): 668-80. https://doi.org/10.1016/j.jacc.2014.11.050.

Petkov V, Mosgoeller W, Ziesche R, Raderer M, Stiebellehner L, Vonbank K, et al. Vasoactive intestinal peptide as a new drug for treatment of primary pulmonary hypertension. J Clin Invest. 2003;111(9):1339-46. https://doi.org/ 10.1172/jci17500.

Plachta DT, Gierthmuehlen M, Cota O, Espinosa N, Boeser F, Herrera TC, et al. Blood pressure control with selective vagal nerve stimulation and minimal side effects. J Neural Eng. 2014;11(3):036011. https://doi.org/10.1088/17412560/11/3/036011.

Premchand RK, Sharma K, Mittal S, Monteiro R, Dixit S, Libbus I, et al. Autonomic regulation therapy via left or right cervical vagus nerve stimulation in patients with chronic heart failure: results of the ANTHEM-HF trial. J Card Fail. 2014;20(11):808-16. https://doi.org/10.1016/j.cardfail.2014.08.009.

Preston IR, Sagliani KD, Warburton RR, Hill NS, Fanburg BL, Jaffe IZ. Mineralocorticoid receptor antagonism attenuates experimental pulmonary hypertension. Am J Physiol Lung Cell Mol Physiol. 2013;304(10):L678-88. https://doi.org/10.1152/ajplung.00300.2012.

Price LC, Wort SJ, Perros F, Dorfmuller P, Huertas A, Montani D, et al. Inflammation in pulmonary arterial hypertension. Chest. 2012;141(1):210-21. https://doi.org/10.1378/chest.11-0793.

Prins KW, Archer SL, Pritzker M, Rose L, Weir EK, Sharma A, Thenappan T. Interleukin-6 is independently associated with right ventricular function in pulmonary arterial hypertension. J Heart Lung Transplant. 2018;37(3):376-84. https://doi.org/10.1016/j.healun.2017.08.011.

Provencher S, Herve P, Jais X, Lebrec D, Humbert M, Simonneau G, Sitbon O. Deleterious effects of beta-blockers on exercise capacity and hemodynamics in patients with portopulmonary hypertension. Gastroenterology. 2006;130(1): 120-6. https://doi.org/10.1053/j.gastro.2005.10.013.

Pulido T, Adzerikho I, Channick RN, Delcroix M, Galie N, Ghofrani HA, et al. Macitentan and morbidity and mortality in pulmonary arterial hypertension. N Engl J Med. 2013;369(9):809-18. https://doi.org/10.1056/NEJMoa1213917.

Qingyan Z, Xuejun J, Yanhong T, Zixuan D, Xiaozhan W, Xule W, et al. Beneficial Effects of Renal Denervation on Pulmonary Vascular Remodeling in Experimental Pulmonary Artery Hypertension. Rev Esp Cardiol (Engl Ed). 2015; 68(7):562-70. https://doi.org/10.1016/j.rec.2014.11.022.

Rabinovitch M, Guignabert C, Humbert M, Nicolls MR. Inflammation and immunity in the pathogenesis of pulmonary arterial hypertension. Circ Res. 2014;115(1):165-75. https://doi.org/10.1161/circresaha.113.301141.

Rich, S., Dantzker, D. R., Ayres, S. M., Bergofsky, E. H., Brundage, B. H., Detre, K. M., . . et al. (1987). Primary pulmonary hypertension. A national prospective study. Ann Intern Med, 107(2), 216-223. doi:https://doi.org/10.7326/00034819-107-2-216

Rich S, Kaufmann E, Levy PS. The effect of high doses of calcium-channel blockers on survival in primary pulmonary hypertension. N Engl J Med. 1992; 327(2):76-81. https://doi.org/10.1056/nejm199207093270203.

Rich S, Martinez J, Lam W, Rosen KM. Captopril as treatment for patients with pulmonary hypertension. Problem of variability in assessing chronic drug treatment. Br Heart J. 1982;48(3):272-7. https://doi.org/10.1136/hrt.48.3.272.

Rothman AM, Arnold ND, Chang W, Watson O, Swift AJ, Condliffe R, et al. Pulmonary artery denervation reduces pulmonary artery pressure and induces histological changes in an acute porcine model of pulmonary hypertension. Circ Cardiovasc Interv. 2015;8(11):e002569. https://doi.org/10. 1161/circinterventions.115.002569.

Rubin LJ, Badesch DB, Barst RJ, Galie N, Black CM, Keogh A, et al. Bosentan therapy for pulmonary arterial hypertension. N Engl J Med. 2002;346(12):896903. https://doi.org/10.1056/NEJMoa012212.

Rubin LJ, Mendoza J, Hood M, McGoon M, Barst R, Williams WB, et al. Treatment of primary pulmonary hypertension with continuous intravenous prostacyclin (epoprostenol). Results of a randomized trial. Ann Intern Med. 1990;112(7): 485-91. https://doi.org/10.7326/0003-4819-112-7-485.

Sabbah HN, Ilsar I, Zaretsky A, Rastogi S, Wang M, Gupta RC. Vagus nerve stimulation in experimental heart failure. Heart Fail Rev. 2011;16(2):171-8. https://doi.org/10.1007/s10741-010-9209-z.

Saouti N, Westerhof N, Postmus PE, Vonk-Noordegraaf A. The arterial load in pulmonary hypertension. Eur Respir Rev. 2010;19(117):197-203. https://doi. org/10.1183/09059180.00002210.

Sastry BK, Narasimhan C, Reddy NK, Raju BS. Clinical efficacy of sildenafil in primary pulmonary hypertension: a randomized, placebo-controlled, double- 
blind, crossover study. J Am Coll Cardiol. 2004;43(7):1149-53. https://doi.org/ 10.1016/j.jacc.2003.10.056.

Scheffers IJ, Kroon AA, Schmidli J, Jordan J, Tordoir JJ, Mohaupt MG, et al. Novel baroreflex activation therapy in resistant hypertension: results of a European multi-center feasibility study. J Am Coll Cardiol. 2010;56(15):1254-8. https:// doi.org/10.1016/j.jacc.2010.03.089.

Schermuly RT, Stasch JP, Pullamsetti SS, Middendorff R, Muller D, Schluter KD, et al. Expression and function of soluble guanylate cyclase in pulmonary arterial hypertension. Eur Respir J. 2008;32(4):881-91. https://doi.org/10.1183/ 09031936.00114407

Seki A, Green HR, Lee TD, Hong L, Tan J, Vinters HV, et al. Sympathetic nerve fibers in human cervical and thoracic vagus nerves. Heart Rhythm. 2014;11(8): 1411-7. https://doi.org/10.1016/j.hrthm.2014.04.032

Simonneau G, Barst RJ, Galie N, Naeije R, Rich S, Bourge RC, et al. Continuous subcutaneous infusion of treprostinil, a prostacyclin analogue, in patients with pulmonary arterial hypertension: a double-blind, randomized, placebocontrolled trial. Am J Respir Crit Care Med. 2002;165(6):800-4. https://doi.org/ 10.1164/ajrccm.165.6.2106079.

Simonneau G, Montani D, Celermajer DS, Denton CP, Gatzoulis MA, Krowka M, et al. Haemodynamic definitions and updated clinical classification of pulmonary hypertension. Eur Respir J. 2019;53(1). https://doi.org/10.1183/ 13993003.01913-2018

Singh TP, Rohit M, Grover A, Malhotra S, Vijayvergiya R. A randomized, placebocontrolled, double-blind, crossover study to evaluate the efficacy of oral sildenafil therapy in severe pulmonary artery hypertension. Am Heart J. 2006; 151(4):851.e851-5. https://doi.org/10.1016/j.ahj.2005.09.006.

Sitbon O, Channick R, Chin KM, Frey A, Gaine S, Galie N, et al. Selexipag for the Treatment of Pulmonary Arterial Hypertension. N Engl J Med. 2015;373(26): 2522-33. https://doi.org/10.1056/NEJMoa1503184.

Sitbon O, Humbert M, Jais X, loos V, Hamid AM, Provencher S, et al. Long-term response to calcium channel blockers in idiopathic pulmonary arterial hypertension. Circulation. 2005;111(23):3105-11. https://doi.org/10.1161/ circulationaha.104.488486.

Soon E, Holmes AM, Treacy CM, Doughty NJ, Southgate L, Machado RD, et al. Elevated levels of inflammatory cytokines predict survival in idiopathic and familial pulmonary arterial hypertension. Circulation. 2010;122(9):920-7. https://doi.org/10.1161/circulationaha.109.933762.

Stavrakis S, Humphrey MB, Scherlag B, Iftikhar O, Parwani P, Abbas M, et al. LowLevel Vagus Nerve Stimulation Suppresses Post-Operative Atrial Fibrillation and Inflammation: A Randomized Study. JACC Clin Electrophysiol. 2017;3(9): 929-38. https://doi.org/10.1016/j.jacep.2017.02.019.

Stavrakis, S., Stoner, J. A., Humphrey, M. B., Scherlag, B., Jackman, W. M., \& Po, S. S. (2019). Transcutaneous electrical vagus nerve stimulation to suppress atrial fibrillation (TREAT AF): A randomized clinical trial. Paper presented at the 40th Heart Rhythm Scientific Sessions, San Francisco, CA.

Sun XQ, Abbate A, Bogaard HJ. Role of cardiac inflammation in right ventricular failure. Cardiovasc Res. 2017;113(12):1441-52. https://doi.org/10.1093/cvr/cvx159.

Taylor DO, Edwards LB, Boucek MM, Trulock EP, Waltz DA, Keck BM, Hertz MI. Registry of the International Society for Heart and Lung Transplantation: twenty-third official adult heart transplantation report--2006. J Heart Lung Transplant. 2006;25(8):869-79. https://doi.org/10.1016/j.healun.2006.05.002.

Thenappan T, Roy SS, Duval S, Glassner-Kolmin C, Gomberg-Maitland M. betablocker therapy is not associated with adverse outcomes in patients with pulmonary arterial hypertension: a propensity score analysis. Circ Heart Fail. 2014;7(6):903-10. https://doi.org/10.1161/circheartfailure.114.001429.

Thenappan T, Shah SJ, Rich S, Gomberg-Maitland M. A USA-based registry for pulmonary arterial hypertension: 1982-2006. Eur Respir J. 2007;30(6):1103-10. https://doi.org/10.1183/09031936.00042107.

Toyoda Y, Thacker J, Santos R, Nguyen D, Bhama J, Bermudez C, et al. Long-term outcome of lung and heart-lung transplantation for idiopathic pulmonary arterial hypertension. Ann Thorac Surg. 2008;86(4):1116-22. https://doi.org/10. 1016/j.athoracsur.2008.05.049.

Tracey KJ. Physiology and immunology of the cholinergic antiinflammatory pathway. J Clin Invest. 2007;117(2):289-96. https://doi.org/10.1172/JCl30555.

Trembath RC, Thomson JR, Machado RD, Morgan NV, Atkinson C, Winship I, et al. Clinical and molecular genetic features of pulmonary hypertension in patients with hereditary hemorrhagic telangiectasia. N Engl J Med. 2001; 345(5):325-34. https://doi.org/10.1056/nejm200108023450503.

Undem BJ, Kollarik M. The role of vagal afferent nerves in chronic obstructive pulmonary disease. Proc Am Thorac Soc. 2005;2(4):355-60; discussion 371352. https://doi.org/10.1513/pats.200504-033SR.
Vaillancourt M, Chia P, Sarji S, Nguyen J, Hoftman N, Ruffenach G, et al. Autonomic nervous system involvement in pulmonary arterial hypertension. Respir Res. 2017;18(1):201. https://doi.org/10.1186/s12931-017-0679-6.

van Campen JS, de Boer K, van de Veerdonk MC, van der Bruggen CE, Allaart CP, Raijmakers PG, et al. Bisoprolol in idiopathic pulmonary arterial hypertension: an explorative study. Eur Respir J. 2016;48(3):787-96. https://doi.org/10.1183/ 13993003.00090-2016.

Velez-Roa S, Ciarka A, Najem B, Vachiery JL, Naeije R, van de Borne P. Increased sympathetic nerve activity in pulmonary artery hypertension. Circulation. 2004;110(10):1308-12. https://doi.org/10.1161/01.cir.0000140724.90898.d3.

Voelkel NF, Tamosiuniene R, Nicolls MR. Challenges and opportunities in treating inflammation associated with pulmonary hypertension. Expert Rev Cardiovasc Ther. 2016;14(8):939-51. https://doi.org/10.1080/14779072.2016. 1180976.

Waldron NH, Fudim M, Mathew JP, Piccini JP. Neuromodulation for the Treatment of Heart Rhythm Disorders. JACC Basic Transl Sci. 2019;4(4):546-62. https://doi.org/10.1016/j.jacbts.2019.02.009.

Yoshida K, Saku K, Kamada K, Abe K, Akashi T, Kishi T, et al. Vagal nerve stimulation restores autonomic balance, super-normalizes right ventricular function and prevents the worsening of right heart failure in chronic pulmonary arterial banding model rats. Eur Heart J. 2018a;39(Suppl 1):ehy565.1205.

Yoshida K, Saku K, Kamada K, Abe K, Tanaka-Ishikawa M, Tohyama T, et al. Electrical Vagal Nerve Stimulation Ameliorates Pulmonary Vascular Remodeling and Improves Survival in Rats With Severe Pulmonary Arterial Hypertension. JACC Basic Transl Sci. 2018b;3(5):657-71. https://doi.org/10. 1016/j.jacbts.2018.07.007.

Yuan JX, Aldinger AM, Juhaszova M, Wang J, Conte JV Jr, Gaine SP, et al. Dysfunctional voltage-gated $\mathrm{K}+$ channels in pulmonary artery smooth muscle cells of patients with primary pulmonary hypertension. Circulation. 1998;98(14):1400-6. https://doi.org/10.1161/01.cir.98.14.1400.

Zanos S. Closed-Loop Neuromodulation in Physiological and Translational Research. Cold Spring Harb Perspect Med. 2018. https://doi.org/10.1101/ cshperspect.a034314.

Zhang H, Zhang J, Chen M, Xie DJ, Kan J, Yu W, et al. Pulmonary Artery Denervation Significantly Increases 6-Min Walk Distance for Patients With Combined Pre- and Post-Capillary Pulmonary Hypertension Associated With Left Heart Failure: The PADN-5 Study. JACC Cardiovasc Interv. 2019;12(3):27484. https://doi.org/10.1016/j.jcin.2018.09.021.

Zhang Y, Mazgalev TN. Arrhythmias and vagus nerve stimulation. Heart Fail Rev. 2011;16(2):147-61. https://doi.org/10.1007/s10741-010-9178-2.

Zhang Y, Popovic ZB, Bibevski S, Fakhry I, Sica DA, Van Wagoner DR, Mazgalev TN. Chronic vagus nerve stimulation improves autonomic control and attenuates systemic inflammation and heart failure progression in a canine high-rate pacing model. Circ Heart Fail. 2009;2(6):692-9. https://doi.org/10, 1161/CIRCHEARTFAILURE.109.873968.

Zhou L, Zhang J, Jiang XM, Xie DJ, Wang JS, Li L, et al. Pulmonary Artery Denervation Attenuates Pulmonary Arterial Remodeling in Dogs With Pulmonary Arterial Hypertension Induced by Dehydrogenized Monocrotaline. JACC Cardiovasc Interv. 2015;8(15):2013-23. https://doi.org/10.1016/j.jcin. 2015.09.015.

Zhu C, Hanna P, Rajendran PS, Shivkumar K. Neuromodulation for Ventricular Tachycardia and Atrial Fibrillation: A Clinical Scenario-Based Review. JACC Clin Electrophysiol. 2019;5(8):881-96. https://doi.org/10.1016/j.jacep.2019.06.009.

\section{Publisher's Note}

Springer Nature remains neutral with regard to jurisdictional claims in published maps and institutional affiliations.

Ready to submit your research? Choose BMC and benefit from:

- fast, convenient online submission

- thorough peer review by experienced researchers in your field

- rapid publication on acceptance

- support for research data, including large and complex data types

- gold Open Access which fosters wider collaboration and increased citations

- maximum visibility for your research: over $100 \mathrm{M}$ website views per year

At $\mathrm{BMC}$, research is always in progress.

Learn more biomedcentral.com/submissions 